\title{
Effects of 3,N-methylglucamine lasalocid on Amyloodinium ocellatum
}

\author{
Daniel J. Oestmann ${ }^{1, *}$, Donald H. Lewis ${ }^{2}$ \\ ${ }^{1} 11150$ Beamer Rd \#416, Houston, Texas 77089, USA \\ ${ }^{2}$ Department of Veterinary Pathobiology, Texas A\&M University, College Station, Texas 77843, USA
}

\begin{abstract}
The cosmopolitan nature of Amyloodinium ocellatum insures the constant possibility of an epizootic in high density mariculture facilities. Chemotherapeutics have shown variable results against the parasite and none are currently approved for use in food fish. The ionophorous antibiotic lasalocid is currently approved for food animal use for the treatment and prophylaxis of coccidian protozoa. The sodium salt of lasalocid was converted to a water-soluble 3, N-methylglucamine salt to evaluate its therapeutic potential for amyloodiniosis. Tomonts and trophonts were incubated in saltwater containing antibiotics (penicillin $100 \mathrm{IU} \mathrm{ml}^{-1}$, streptomycin $100 \mu \mathrm{g} \mathrm{ml}^{-1}$ ) and 100 to $0.001 \mathrm{ppm}$ concentrations of 3,N-methylglucamine lasalocid (3NMG-lasalocid). The $24 \mathrm{~h}$ tomont division rate and in vitro trophont density decreased in a dose-dependent manner when exposed to $3 \mathrm{NMG}$-lasalocid concentrations between 100 and $0.001 \mathrm{ppm}$. Motile dinospores did not excyst until the 3NMG-lasalocid concentration was reduced to $0.001 \mathrm{ppm}$, and then at a concentration $44 \%$ that of controls. Cracked and ruptured tomonts were observed by scanning electron microscopy and degenerated internal membranous structures of trophonts were observed by transmission electron microscopy. Trophont infection on 0.5 to $1 \mathrm{~g}$ red drum Sciaenops ocellatus fry exposed to 2.5 dinospores $\mathrm{ml}^{-1}$ in $6.0 \mathrm{l}$ of saltwater was reduced by $80 \%$ on gill filaments and $54 \% \mathrm{~mm}^{-2}$ surface area when treated with $0.1 \mathrm{ppm}$ 3NMG-lasalocid. Infection was prevented at $1.0 \mathrm{ppm}$ 3NMG-lasalocid
\end{abstract}

KEY WORDS: Lasalocid Amyloodinium - Ionophore $\cdot$ Red drum

\section{INTRODUCTION}

Management measures such as high water turnover rates, micro-filtration, and sanitation are used to control Amyloodinium ocellatum in mariculture facilities, but the ubiquitous dispersal of the parasite insures the possibility of an epizootic. Fresh water or formalin immersion bath protocols are effective management procedures for quarantined fish in laboratory and pet fish facilities (Lawler 1979, Paperna 1984a, Noga \& Bower 1987), but are impractical for large production facilities. Several herbicides, disinfectants, salinity concentrations, and antiprotozoal drugs have been tested for the control of amyloodiniosis with variable results (Dempster 1955, Lawler 1977, Johnson 1984. Paperna 1984b, Lewis et al. 1988).

•E-mail: oestmann@hal-pc.org
Dinospores have been considered the most susceptible stage of the 3-phase life cycle (sessile feeding trophont/encysted reproductive tomont/free-swimming infective dinospores) of Amyloodinium ocellatum. Copper compounds (0.75 ppm free copper) can be used to treat an outbreak of $A$. ocellatum by eliminating the dinospore, but this dose may be harmful to most fish species (Paperna 1984a). Most fish species will survive and amyloodiniosis can be prevented or controlled at 0.15 ppm free copper (Dempster 1955, Johnson 1984). The antimalarial drug chloroquine has been demonstrated to have therapeutic potential. Chloroquine eliminated dinospore activity in vitro after $24 \mathrm{~h}$ at $2.5 \mu \mathrm{g} \mathrm{ml}^{-1}$, and oral doses of $50 \mathrm{mg} \mathrm{kg}^{-1}$ body weight produced inhibitory tissue drug levels (>5.0 $\mu \mathrm{g}$ drug $\mathrm{ml}^{-1}$ ) for $7 \mathrm{~d}$ with most of the drug disappearing from the tissue within $30 \mathrm{~d}$ (Lewis et al. 1988). However, due to governmental regulations and environmental concerns, 


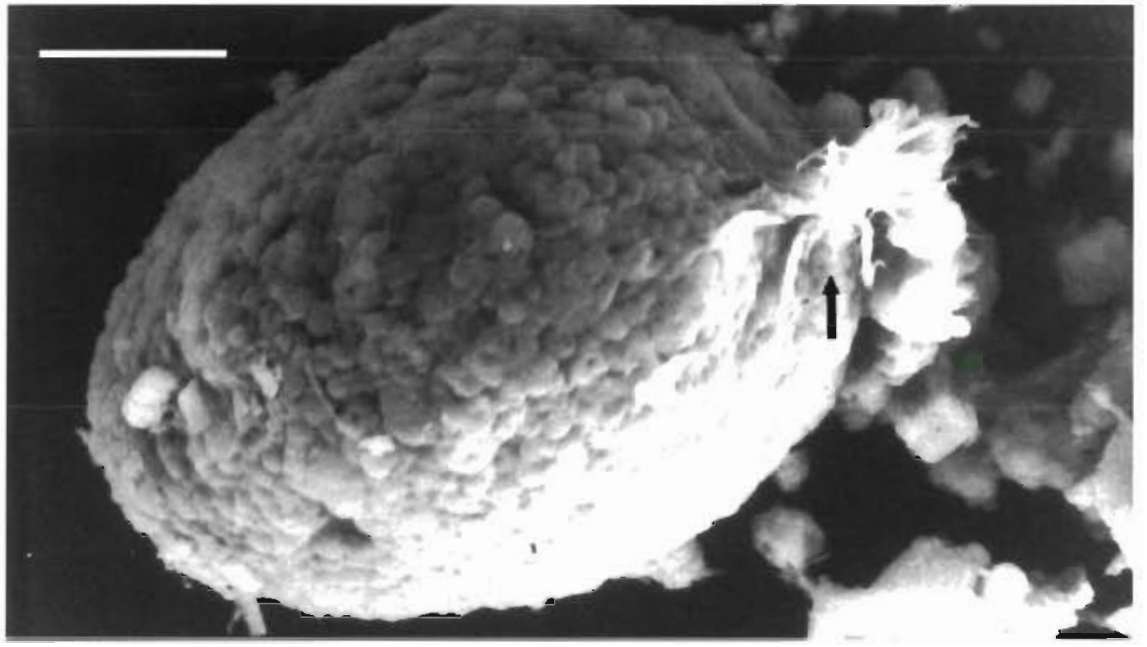

Fig. 1. Amyloodinium ocellatum. Fortyeight hour cell culture trophont. Thecal opening (arrow) at bottom of trophont from which rhizoids and stomopode emerge. Also thought to be the site of ion pump for osmotic regulation at varying salinity. $\times 2000$ (scale bar $=$ 10 1 ! !m! chloroquine is unlikely to be approved for aquatic food animal use.

Amyloodinium ocellatum has a temperature-dependent salinity tolerance range of 1 to 78 ppt (Paperna $1984 \mathrm{~b}$ ), suggesting the presence of a powerful and efficient ion pump. An opening at the base of the thecal plate shell of the trophont, from which the rhizoid complex and stomopode emerge (Fig. 1), is subtended by a thin electron-dense layer of densely staining material, which swells to a massive osmiophilic ring at the perimeter (Lom \& Lawler 1973). The author theorized that this is the site of an ion pump regulating ionic equilibrium at variable salinity.

The polyether ionophorous antibiotics disrupt internal membranous organelles by the stimulation of energy-linked transport in mitochondria, increased membrane permeability, and the formation of lipophilic complexes with sodium cations and their transport across membranes into the cell (Smith et al. 1981, Mehihorn et al. 1983, Smith \& Galloway 1983, Daszak et al. 1991). The ion pump thought to be present in Amyloodinium ocellatum would be a likely target for ionophorous drugs with ion influx potential. The sodium salt of lasalocid is labeled for use as a feed additive (Avatec ${ }^{\mathrm{M}}$, poultry; Bovatec ${ }^{\mathrm{TM}}$, cattle) for the prevention and treatment of coccidian intestinal parasites. Therefore, the potential of lasalocid as a treatment or prophylactic for amyloodiniosis was evaluated.

The ionophorous antibiotics (e.g. monensin, romensin, salinomycin, lasalocid) typically have low water solubility $(0.2 \%$ in water for lasalocid). Dissolving lasalocid in ethanol $(2.1 \%$ solubility in ethanol) and adding to saltwater produced a flocculent precipitate. Therefore, the sodium salt of lasalocid was converted to an $\mathrm{N}$-methylglucamine salt to enhance its water solubility for use in this study.

\section{MATERIALS AND METHODS}

Lasalocid conversion. Fifty grams of lasalocid provided by the manufacturer (Hoffmann-La Roche, Inc., Nutley, NJ, USA) as a sodium salt (molecular weight 612.78 ) was dissolved in $500 \mathrm{ml}$ chloroform and placed into a separatory funnel. The sodium lasalocid was converted to lasalocid free acid by adding an equal volume of $1 \mathrm{~N} \mathrm{HCl}$ to the solution, shaking and allowing the acid/chloroform layers to separate. The bottom chloroform layer was drained into another separatory funnel and the process repeated with a second $500 \mathrm{ml}$ of $1 \mathrm{~N} \mathrm{HCl}$.

The chloroform layer was drained into another separatory funnel, an equal volume of deionized water added, and the contents shaken and the aqueous/chloroform layers allowed to separate. The chloroform layer was drained into another separatory funnel and a second volume of deionized water added and the process repeated. The chloroform layer was drained into a beaker and evaporated under water faucet vacuum in a heated water bath $\left(37^{\circ} \mathrm{C}\right)$ until a thick paste formed ( 48 to $72 \mathrm{~h}$ ).

One hundred grams of $\mathrm{N}$-methylglucamine (molecular weight 195.2) was dissolved in $500 \mathrm{ml}$ methanol and combined with the lasalocid free acid paste. The volume was reduced $90 \%$ by heating $\left(37^{\circ} \mathrm{C}\right)$ while stirring to evaporate the methanol, forming a thick oil (18 to $24 \mathrm{~h}$ ). The preparation was dissolved in an adequate amount of hexane (about 1.0 l) and chilled overnight at $4^{\circ} \mathrm{C}$ while stirring to precipitate the $3, \mathrm{~N}$-methylglucamine-lasalocid crystals (3NMG-lasalocid). The 3 NMG-lasalocid crystals were collected by filtration and the filter paper soaked in deionized water to dissolve the crystals. The water was filtered through a second filter paper to remove non-water-soluble particles and the filtrate lyophilized to obtain pure 3NMG- 
Table 1 Saltwater media (SM) formulations for cell culture propagation. Sterilized by $0.45 \mu \mathrm{m}$ filtration. Based on IO2/HBSS use by Noga $(1987,1989,1992)$

\begin{tabular}{|c|c|c|}
\hline & $\begin{array}{c}\text { SM-30 ppt } \\
(g \mid l)\end{array}$ & $\begin{array}{c}\text { SM-10 ppt } \\
\left.(g]^{-1}\right)\end{array}$ \\
\hline $\mathrm{NaCl}$ & 24.29 & 8.10 \\
\hline $\mathrm{MgSO}_{4} \cdot 7 \mathrm{H}_{2} \mathrm{O}$ & 4.85 & 1.62 \\
\hline $\mathrm{MgCl}_{2} \cdot 6 \mathrm{H}_{2} \mathrm{O}$ & 3.49 & 1.16 \\
\hline $\mathrm{CaCl}_{2} \cdot 2 \mathrm{H}_{2} \mathrm{O}$ & 1.17 & 0.39 \\
\hline $\mathrm{KCl}$ & 0.77 & 0.26 \\
\hline $\mathrm{NaHCO}_{3}$ & 0.38 & 0.13 \\
\hline $\mathrm{Na}_{2} \mathrm{HPO}_{4} \cdot 7 \mathrm{H}_{2} \mathrm{O}$ & 0.07 & 0.023 \\
\hline $\mathrm{KH}_{2} \mathrm{PO}_{4}$ & 0.045 & 0.015 \\
\hline Glucose & - & 1.0 \\
\hline Penicillin & $100[\mathrm{U} \mathrm{ml}]^{-1}$ & $100 \mathrm{IU} \mathrm{ml}^{-1}$ \\
\hline Streptomycin & $100 \mu \mathrm{g} \mathrm{ml}^{-1}$ & $100 \mu \mathrm{g} \mathrm{ml}^{-1}$ \\
\hline $\mathrm{pH}$ & 7.4 & 7.4 \\
\hline Specific gravity & $1.023 \mathrm{~g} \mathrm{ml}^{-1}$ & $1.007 \mathrm{~g} \mathrm{ml}^{-1}$ \\
\hline
\end{tabular}

lasalocid. Samples of the final product, sodium lasalocid, and $\mathrm{N}$-methylglucamine were submitted to the Texas A\&M University chemistry department for nuclear magnetic resonance (NMR) analysis

Tomont treatment. The protocol for collecting microbe-free Amyloodinium ocellatum tomonts is described elsewhere (Oestmann \& Lewis 1995). In brief, tomonts were collected by osmotic shock, purified by Percoll ${ }^{\otimes}$ gradient centrifugation, enumerated, and distributed 30000 tomonts in 30 ppt saltwater medium, SM-30; Table 1) into seven $25 \mathrm{~cm}^{2}$ cell culture flask. After $1 \mathrm{~h}$ settling time, the SM-30 used to prepare the tomonts was aspirated from 6 of the flasks and replaced with SM-30 supplemented with 10-fold dilutions of 3NMG-lasalocid (100 to 0.001 ppm 3NMGlasalocid in SM-30) with the seventh flask serving as a control. At $24 \mathrm{~h}$ incubation the tomont division rates were assessed by observing with an inverted microscope. Dinospores were enumerated at $72 \mathrm{~h}$ incubation by aspirating an aliquot with a $37 \%$ formalin coated Pasteur pipette and loading onto a hemocytometer (Bower et al. 1987). Samples were removed from the flasks and fixed overnight at $4^{\circ} \mathrm{C}$ in $5 \%$ glutaraldehyde and $4 \%$ paraformaldehyde in $0.1 \mathrm{M}$ cacodylate buffer (Karnovsky 1965). The fixative was replaced with $0.1 \mathrm{M}$ sodium cacodylate buffer the next morning in preparation for scanning electron microscopy.

3NMG-lasalocid toxicity to red drum cell culture. The toxic effect of 3NMG-lasalocid was assessed on red drum Sciaenops ocellatus dorsal fin cell (RDFC) monolayers. Three-day-old monolayers were trypsinized, enumerated, and their viability assessed by trypan blue exclusion. Seven $25 \mathrm{~cm}^{2}$ cell culture flasks were prepared using $5 \mathrm{ml}$ aliquots of $1.62 \times 10^{6} \mathrm{RDFC}$ $\mathrm{ml}^{-1}$ in L-15 (BioWhittaker, Inc., Walkersville, MD, USA) cell culture medium supplemented with $10 \%$ fetal bovine serum, $1 \%$ L-glutamine, and penicillin (100 $\left.\mathrm{IU} \mathrm{ml}^{-1}\right)$ and streptomycin $(100 \mu \mathrm{g} \mathrm{ml}-1)$. Confluent monolayers had formed after $24 \mathrm{~h}$ incubation at $26^{\circ} \mathrm{C}$, at which time the media from 6 flasks were aspirated and replaced with L-15 containing supplements plus 10 -fold dilutions of 3NMG-lasalocid (100 to 0.001 ppm 3NMG-lasalocid in L-15) with the seventh flask serving as a control. Incubation continued at $26^{\circ} \mathrm{C}$ for $3 \mathrm{~d}$, at which time the RDFC monolayers were trypsinized, enumerated, and their viability assessed by trypan blue exclusion.

In vitro trophont treatment. The effect of $3 \mathrm{NMG}$ lasalocid was evaluated on in vitro trophonts propagated on red drum dorsal fin cells grown as aggregates (Oestmann 1994). Dinospores emerging from microbe-free tomonts attached and transformed into trophonts on RDFC aggregates in 10 ppt saltwater media (SM-10; Table 1). Aliquots of infected RDFC aggregates were divided into 3 siliconized glass Leighton tubes. One hour after exposure to dinospores, the SM-10 from 6 tubes was aspirated and replaced with SM-10 containing 10 -fold dilutions of 3NMGlasalocid (100 to $0.001 \mathrm{ppm}$ 3NMG-lasalocid in SM-10) with the seventh tube serving as a control. The tubes were then placed in a $23^{\circ} \mathrm{C}$ incubator on a rotary table and gently rotated to keep the aggregates suspended At 24 and 48 h incubation trophont densities were evaluated microscopically and aggregate samples fixed as described above for tomonts and subsequently fixed in osmium tetroxide for transmission electron microscopy.

In vivo trophont treatment. Six red drum fry 10.5 to $1 \mathrm{~g})$ were placed in each of 6 small plastic tanks in $6.0 \mathrm{l}$ saltwater, 20 ppt (Fritz Supersalt; Fritz Chemical Co., Dallas, TX, USA) for $1 \mathrm{wk}$ acclimation. Tank 1 was then treated with 2.5 dinospores $\mathrm{ml}^{-1}$ (15000 dinospores), tank 2 was treated with 2.5 dinospores $\mathrm{ml}^{-1}$ plus 0.1 ppm 3NMG-lasalocid, tank 3 was treated with $0.1 \mathrm{ppm}$ 3NMG-lasalocid alone. Tank 4 was treated with 2.5 dinospores $\mathrm{ml}^{-1}$ plus $1.0 \mathrm{ppm}$ 3NMG-lasalocid while tank 5 was treated with $1.0 \mathrm{ppm} 3 \mathrm{NMG}$-lasalocid alone. Tank 6 served as the non-treated control. After $24 \mathrm{~h}$ exposure, the fish were killed by cervical transection and trophont load per gill filament assessed microscopically (10 filaments per arch on each of 6 fish averaged). The surface area trophont load was also assessed on the tail, dorsal, anal, and pectoral fin clips (average $\mathrm{mm}^{-2}$ ).

\section{RESULTS}

The conversion of sodium lasalocid to an N-methy]glucamine salt is very inefficient, yielding only about $50 \mathrm{mg}$ of final product from $50 \mathrm{~g}$ of sodium lasalocid. 


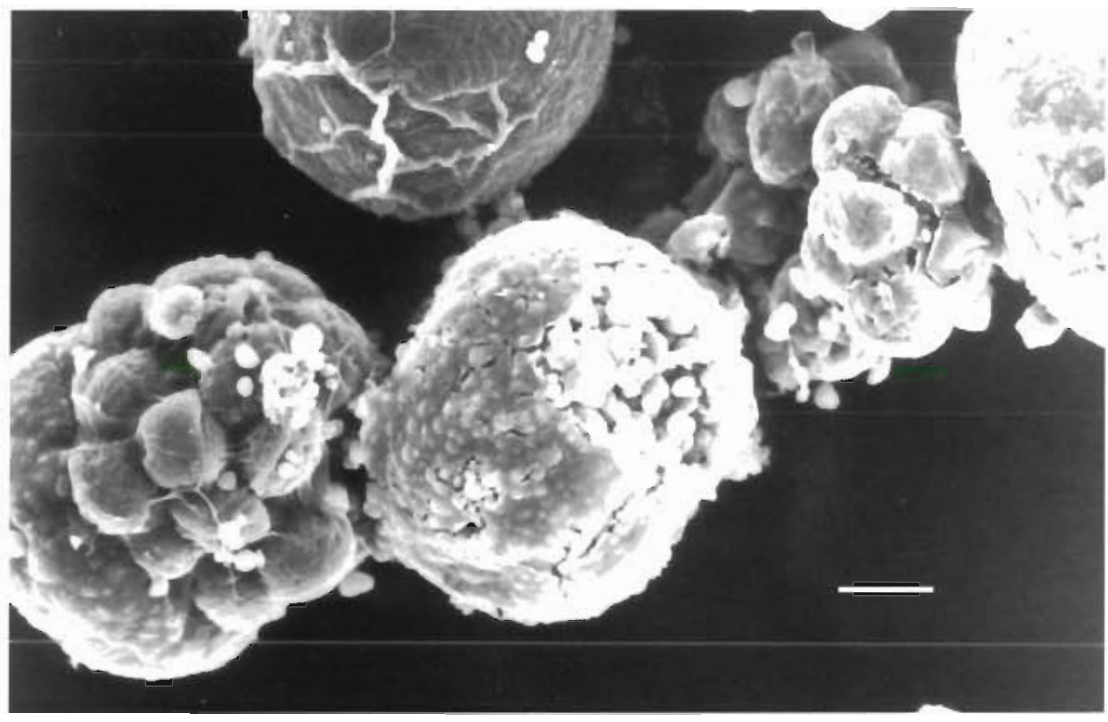

Fig. 2. Amyloodinium ocellatum. Tomonts incubated $72 \mathrm{~h}$ in $0.1 \mathrm{ppm}$ 3NMG-lasalocid. Cracked and ruptured tomonts spilling white starch grains; irregular and non-dividing tomonts also can be seen. $\times 1000$ (scale bar $=10 \mu \mathrm{m}$ )

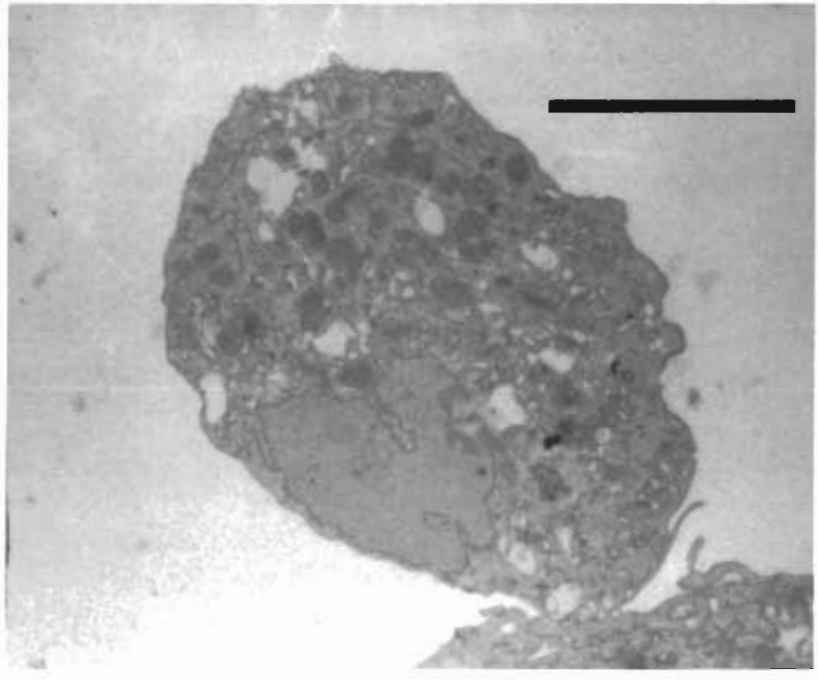

Fig. 3. Amyloodinium ocellatum. Twenty-four hour cell culture trophont with no exposure to 3NMG-lasalocid. Cytoplasm of trophont and RDFC aggregate shows orderly cellular structure. $\times 5000$ (scale bar $=10 \mu \mathrm{m}$ )

The sodium lasalocid was expected to convert to a 2, N-methylglucamine lasalocid. However, NMR analysis revealed $3, N$-methylglucamine substitutions had taken place at the sodium and both hydroxyl group positions, yielding a final product with a molecular weight of 1176.38 .

RDFC monolayers treated with 3NMG-lasalocid exhibited a dose-dependent toxic response. At $24 \mathrm{~h}$ the $100 \mathrm{ppm}$ 3NMG-lasalocid treated monolayer had sloughed and the $1.0 \mathrm{ppm}$ 3NMG-lasalocid treated cells had retracted, rounded edges with many floating cells. The 1.0 to 0.001 ppm 3NMG-lasalocid treated monolayers appeared healthy. After 3 d exposure to 3NMG-lasalocid the control monolayer viability was
$96 \%$ while the 10 to $0.001 \mathrm{ppm} 3 \mathrm{NMG}$-lasalocid treatment viabilities were $93,98,98,97$, and $98 \%$ respectively. The cell count also was inversely proportional to the 3 NMG-lasalocid dose. The control cell count was $6.8 \times 10^{5} \mathrm{RDFC} \mathrm{ml}^{-1}$ while the cell counts for the 10 to $0.001 \mathrm{ppm} 3 \mathrm{NMG}$-lasalocid treatment were $1.3 \times 10^{5}$, $5.2 \times 10^{5}, 6.4 \times 10^{5}, 6.9 \times 10^{5}$, and $6.8 \times 10^{5} \mathrm{RDFC} \mathrm{ml}^{-1}$ respectively

The $24 \mathrm{~h}$ tomont division rate also decreased in a dose-dependent manner when treated with $3 \mathrm{NMG}$ lasalocid. The control tomont division rate was $82 \%$ compared to $59,69,75,78,80$, and $81 \%$ (average of 3 trials) observed for the 100 to $0.001 \mathrm{ppm} 3 \mathrm{NMG}$-lasalocid dilutions respectively. Irregular division, cracked and ruptured tomonts, and release of starch grains were observed by scanning electron microscopy of 3NMG-lasalocid treated tomonts (Fig. 2). Dinospores excysted but were deformed and non-motile at 1 to $0.01 \mathrm{ppm}$ 3NMG-lasalocid. Motile dinospores did not excyst until the 3NMG-lasalocid concentration was reduced to $0.001 \mathrm{ppm}$, and then at a concentration $44 \%$ that of controls (27800 dinospores $\mathrm{ml}^{-1}$ for control vs 122.50 dinospores $\mathrm{ml}^{-1}$ at $0.001 \mathrm{ppm} 3 \mathrm{NMG}$ Iasalocid)

Subjectively, the in vitro trophont infection on RDFC aggregates was observed to decrease in a dose-dependent manner Trophonts were not present in sufficient numbers for electron microscopic examination until the $3 \mathrm{NMG}$-lasalocid concentration was decreased to 0.01 ppm. Effects of the 3 NMG-lasalocid treatment observed by transmission electron microscopy were similar to effects previously described in coccidian parasites (Ryley 1969, Scholtyseck et al. 1971, 1972, Vetterling et al. 1973, Mehlhorn et al. 1983, Smith \& Galloway 1983, Daszak et al. 1991) (Figs. 3 \& 4). Internal membranous organelles of trophonts were disrupted and degener- 


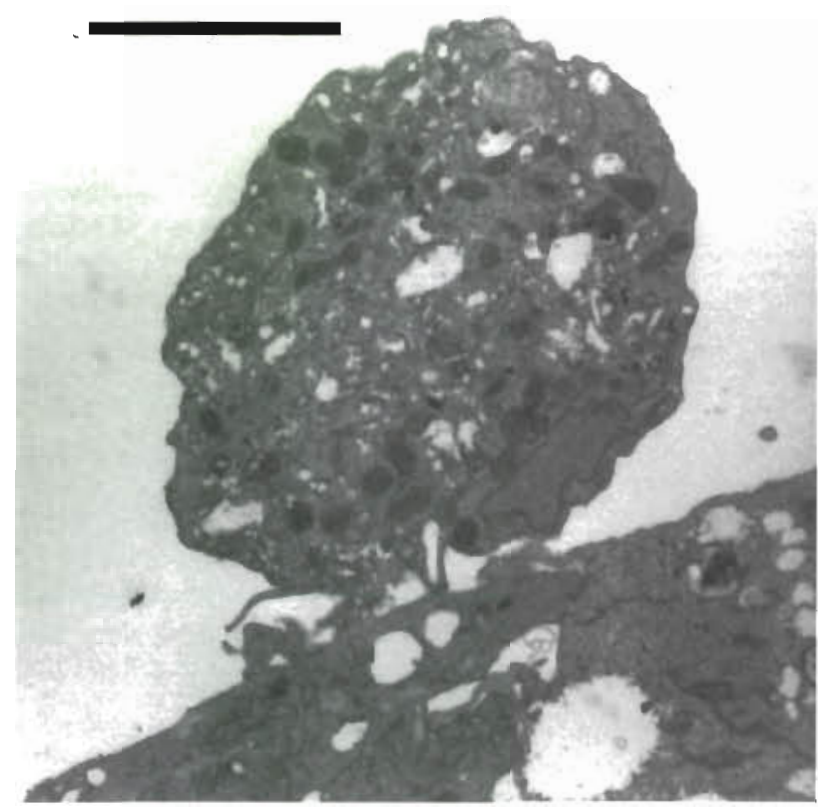

Fig. 4. Amyloodinium ocellatum. Twenty-four hour cell culture trophont incubated in $0.01 \mathrm{ppm}$ 3NMG-lasalocid. Cytoplasm of trophont and RDFC aggregate are disrupted with increased vacuolization. $\times 5000$ (scale bar $=10 \mu \mathrm{m}$ )

ated, indicative of the actions of ionophorous antibiotics (Fig. 5) documented in the previous reports.

Trophont infection on 0.5 to $1 \mathrm{~g}$ red drum fry exposed to 2.5 dinospores $\mathrm{ml}^{-1}$ in $6.0 \mathrm{l}$ of saltwater ( $20 \mathrm{ppt}$ ) was reduced by $80 \%$ on gill filaments compared to the tank treated with dinospores alone (mean 6.69 vs 1.37 trophonts per filament) when treated with $0.1 \mathrm{ppm}$ 3NMG-lasalocid $(p<0.01)$. The gill lamellae of fish in tanks treated with dinospores alone exhibited severe degeneration, clubbing, and necrosis. Infection was reduced by $54 \% \mathrm{~mm}^{-2}$ surface area (mean 11.55 vs 5.34 trophonts $\mathrm{mm}^{-2}$ ) in the $0.1 \mathrm{ppm}$ 3NMG-lasalocid treated tank $(\mathrm{p}<0.01)$. Fish in the control tank, $0.1 \mathrm{ppm}$ 3NMG-lasalocid treated tank, $1.0 \mathrm{ppm}$ 3NMG-lasalocid treated tank, and the tank treated with 2.5 dinospores $\mathrm{ml}^{-1}$ and $1.0 \mathrm{ppm}$ 3NMG-lasalocid showed no sign of infection or gill necrosis. All fish survived to the experimental end point, indicating that 3NMG-lasalocid may not be toxic when used at the described dosages for $24 \mathrm{~h}$.

\section{DISCUSSION}

Amyloodinium ocellatum is an important parasite in mariculture facilities on the U.S. Gulf of Mexico coast. The lack of effective treatment measures and the cosmopolitan nature of the parasite insures epizootics with

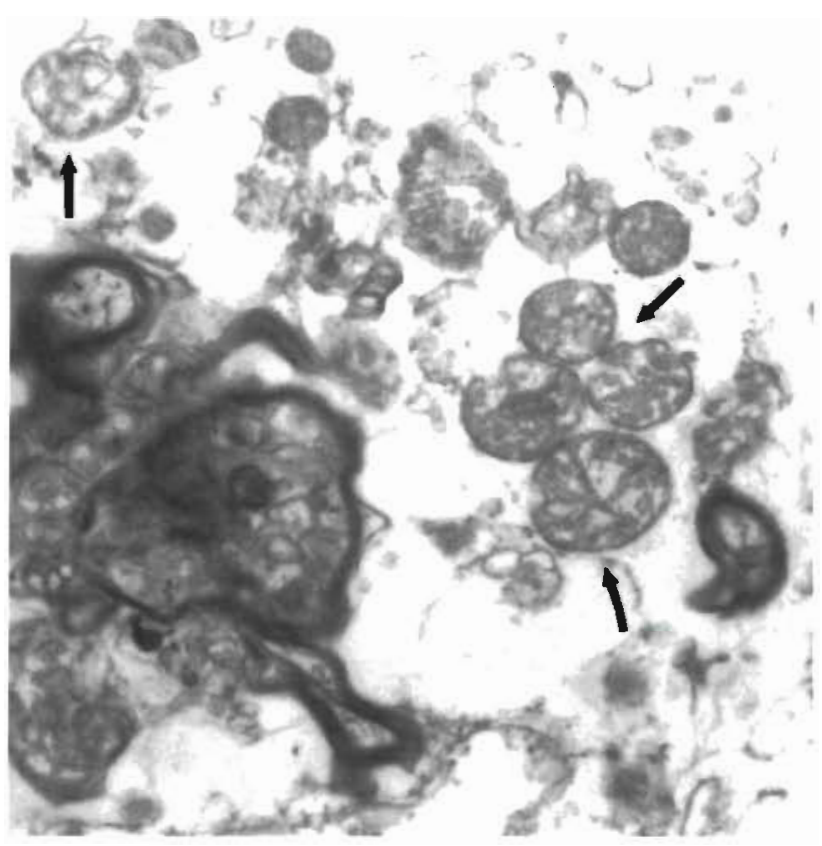

Fig. 5. Amyloodinium ocellatum. Degenerated mitochondria (arrows) of trophonts incubated in 0.01 ppm 3NMG-lasalocid. $\times 20000$

high morbidity and mortality will likely continue to occur. Lasalocid currently is labeled for use in food animals (poultry and cattle) for the prevention of coccidian intestinal protozoa. A water-soluble 3NMG-lasalocid was demonstrated in these studies to be effective against 2 stages of the life cycle (tomont and trophont) previously considered refractory to treatment (Johnson 1984, Paperna 1984a). In vitro trophont infection was significantly reduced at $0.1 \mathrm{ppm}$ and eliminated at $1.0 \mathrm{ppm}$ 3NMIG-lasalocid, with motile dinospore excystment from tomonts reduced or prevented at levels as low as $0.001 \mathrm{ppm}$. Toxicity to $0.5-1.0 \mathrm{~g}$ red drum fry was not evident at these dosages.

This drug may be an effective therapeutant for a broad range of common protozoal diseases common in aquaculture (e.g Ichthyobodo, Ichthyophthirius multifiliis in freshwater fish and gregarines in shrimp). Further studies on the drug's toxicity to various cultured fish species, tissue residue levels, efficacy against other protozoal parasites, and possible effluent levels are warranted. A full scale field trial to test the treatment and prophylactic potential of 3NMG-lasalocid should be undertaken for amyloodiniosis.

Acknowledgements. The authors thank Mrs Willie Mae Charanza for her technical support and help, Dr Steve Silber for the nuclear magnetic resonance analysis, and Dr Helga Sittertz-Bhatkar for her electron microscope expertise. 


\section{LITERATURE CITED}

Bower CE, Turner DT, Biever RC (1987) A standardized method of propagating the marine fish parasite Amyloodinium ocellatum. J Parasitol 73:85-88

Daszak P, Ball SJ, Pittilo RM, Norton CC (1991) Ultrastructural studies of the effects of the ionophore lasalocid on Eimeria tenella in chickens. Z Parasitenkd 77 : $224-229$

Dempster RP (1955) The use of copper sulfate as a cure for fish diseases caused by parasitic dinoflagellates of the genus Oodinium. Zoologica 40:133-138

Johnson SK (1984) Evaluation of several chemicals for control of Amyloodinium ocellatum, a parasite of marine fishes. Fish Diseases Diagnostic Laboratory Publ FDDL-M5. Texas A\&M University, College Station, $p$ 1-4

Karnovsky MJ (1965) A formaldehyde-glutaraldehyde fixative of high osmolality for use in electron microscopy. J Cell Biol 27:137 A

Lawier AR (1977) The parasitic dinofiageiliate Amyioodinium ocellatum in marine aquaria. Drum Croaker 17:17-20

Lawler AR (1979) North American fishes reported as hosts of Amyloodinium ocellatum (Brown, 1931). Drum Croaker 19:8-14

Lewis DH, Wenxing W, Ayers A, Arnold CR (1988) Preliminary studies on the use of chloroquine as a systemic chemotherapeutic agent for amyloodiniosis in red drum (Sciaenops ocellatus). Contr mar Sci, Suppl 30:183-189

Lom J, Lawler AR (1973) An ultrastructural study on the mode of attachment in dinoflagellates invading gills of cyprinodontidae. Protistologica 9:293-309

Mehlhorn $\mathrm{H}$, Pooch $\mathrm{H}$, Raether W (1983) The action of polyether ionophorous antibiotics (monensin, salinomycin, lasalocid) on developmental stages of Eimeria tenella (coccidia, sporozoa) in vivo and in vitro: study by light and electron microscopy. Z Parasitenkd 69:457-471

Noga EJ (1987) Propagation in cell culture of the dinoflagellate Amyloodinium, an ectoparasite of marine fishes. Science 23:1302-1304

Noga EJ (1989) Culture conditions affecting the in vitro

Responsible Subject Editor: W. Körting, Hannover, Germany propagation of Amyloodinium ocellatum. Dis aquat Org $6: 137-143$

Noga EJ (1992) Immune response to ectoparasite protozoa: the infectivity assay. In: Stolen JS, Fletcher TC, Anderson DP, Kaattari SL, Rowley AF (ed) Techniques in fish immunology. SOS Publications, Fair Haven, NJ, p 167-175

Noga EJ, Bower CE (1987) Propagation of the marine dinoflagellate Amyloodinium ocellatum under germ-free conditions. J Parasitol 73:924-928

Oestmann DJ (1994) In vitro propagation of Amyloodinium ocellatum for immunologic and therapeutic studies of amyloodinium in red drum (Sciaenops ocellatus). PhD dissertation, Texas A\&M University, College Station

Oestmann DJ, Lewis DH (1995) A method for producing microbe-free Amyloodinium ocellatum (Brown) with Percoll ${ }^{\text {W. }}$. Vet Parasitol (in press)

Paperna I (1984a) Chemical control of Amyloodinium ocellatum (Brown, 1931) (Dinoflagellida) infections: in vitro tests and treatment trials with infected fishes. Aquaculture 38: $\hat{1}-\hat{1} 8$

Paperna [ (1984b) Reproduction cycle and tolerance to temperature and salinity of Amyloodinium ocellatum (Brown. 1931) (Dinoflagellida). Ann Parasitol comp (Paris) 59:7-30

Ryley JF (1969) Ultrastructural studies on the sporozoite of Eimeria tenella. Parasitology 37:67-72

Scholtyseck E, Mehlhorn H, Hammond DM (1971) Fine structure of macrogametes and oocytes of coccidia and related organisms. Z Parasitenkd 37:1-43

Scholtyseck E, Mehlhorn H, Hammond DM (1972) Electron microscope studies of microgametogenesis in coccidia and related groups. Z Parasitenkd 38:95-131

Smith CK, Galloway RB (1983) Influence of monensin on cation influx and glycolysis of Eimeria tenella sporozoites in vitro. J Parasitol 69:666-670

Smith CK II, Galloway RB, White SL (1981) Effect of ionophores on survival, penetration, and development of Eimeria tenella sporozoites in vitro. J Parasitol 67:511-516

Vetterling JM, Pacheco ND, Madden PA (1973) Ultrastructure of dormant, activated and intracellular sporozoites of Eimeria adenoeides and E. tenella. J Parasitol 59:15-27

Manuscript first received: May 29, 1995

Revised version accepted: September 20, 1995 